\title{
First North Pacific records of the pointy nosed blue chimaera, Hydrolagus cf. trolli (Chondrichthyes: Chimaeriformes: Chimaeridae)
}

\author{
Amber N. Reichert ${ }^{1 *}$, Lonny Lundsten ${ }^{2}$ and David A. Ebert ${ }^{1,3}$
}

\begin{abstract}
The occurrence of Hydrolagus cf. trolli is reported for the first time from the central and eastern North Pacific Ocean. This is a geographic range extension for this species, as it was previously only known to occur in the southern Pacific Ocean off of Australia, New Zealand, and New Caledonia.
\end{abstract}

Keywords: Hydrolagus trolli, Northern Hemisphere, Range extension

\section{Introduction}

Currently there are 38 recognized species of short-nosed chimaeras (family Chimaeridae), making it the most species rich family in the order Chimaeriformes (Kemper et al. 2015). The family has two recognized genera that are separated by the presence (Chimaera) or absence (Hydrolagus) of an anal fin. The genus Hydrolagus is the more diverse of the two genera with 22 species (Didier et al., 2012). Fifteen of these species are recognized as occurring in the Pacific Ocean, but only five species are known in the eastern Pacific (James et al. 2009). These five Hydrolagus species are geographically dispersed around the Galapagos Island, the southeastern Pacific along the coasts of Chile and Peru, and lastly in the northeastern Pacific (James et al. 2009). Until recently Hydrolagus colliei (Lay and Bennett, 1839) and Hydrolagus melanophasma (James, Ebert, Long, and Didier, 2009) were the only species confirmed to occur in the northeastern Pacific. Hydrolagus colliei is found from Alaska to Costa Rica, while $H$. melanophasma occurs off southern California, USA to northern Chile (Angulo et al., 2014; Aguirre-Villaseñor et al. 2013). However, a third species of Hydrolagus, first noted but not identified by Ebert (2003), had been observed by remotely operated vehicle (ROV) at

\footnotetext{
* Correspondence: areichert@mlml.calstate.edu

'Pacific Shark Research Center, Moss Landing Marine Laboratories, 8272 Moss Landing Road, Moss Landing, CA 95039, USA

Full list of author information is available at the end of the article
}

Davidson Seamount off central California at a depth greater than $2000 \mathrm{~m}$. Lundsten et al. 2009 identify Hydrolagus trolli from the Davidson Seamount, however provide no descriptive information. Central North Pacific records of chimaeras are few, with only the purple chimaera, Hydrolagus purpurescens (Gilbert 1905), being reported from the Hawaiian Islands.

The pointy nosed blue chimaera, Hydrolagus trolli (Didier and Séret 2002), was described from 23 specimens. The holotype is a male specimen measuring $1030 \mathrm{~mm}$ (TL) that was captured by bottom trawl off New Caledonia $\left(20^{\circ} 44.90^{\prime} \mathrm{S}, 167^{\circ} 43.10^{\prime} \mathrm{E}\right)$ at a bottom depth of $1246 \mathrm{~m}$. Hydrolagus trolli is a little known chimaera species usually found at depths ranging 610$2000 \mathrm{~m}$ (Last and Stevens 2009). To date, this species has only been confirmed from the southwestern Pacific, off Australia, New Zealand, New Caledonia, the Lord Howe Rise and Norfolk Ridge (Last and Stevens 2009). This species, or a similar looking species, is known to occur over a much broader geographical range in the Southern Hemisphere, e.g. South Africa (Ebert and van Hees, 2015), but to date there are no descriptions of this species from the Northern Hemisphere. A specimen of $H$. cf. trolli was recorded off Chile (as H. pallidus in Andrade \& Pequeño, 2006), (Bustamante et al. 2012). A potential specimen of $H$. trolli was collected off St. Paul Island in the Southern Indian Ocean but identification could not be confirmed due to poor condition (Didier and Séret 2002). 
During a series of remotely operated vehicle (ROV) deep-sea surveys off the California coast and west of the Hawaiian Islands conducted by the Monterey Bay Aquarium Research Institute (MBARI), a large, bluish, short-nosed Hydrolagus species was observed on several occasions. Here we report on the occurrence of these Hydrolagus specimens that we have identified as Hydrolagus cf. trolli.

\section{Materials and methods}

Observations of Hydrolagus cf. trolli were videotaped in situ using either a Panasonic WVE550 3-chip standard definition or Ikegami HDL-40 high definition video camera during deep-water surveys using the ROV Tiburon off the coast of California and Hawaii. Using MBARI's Video Annotation and Reference System database (VARS, Schlining et al. 2006), videotaped observations were entered into a searchable database and merged with ancillary data so that latitude, longitude, depth, and CTD information is known for every observation. We queried VARS for observations identified as potentially being these species based on macroscopic characters. Due to inconsistencies in the calibrated laser system which is used for estimating organism size, we were unable to obtain lengths of our specimens.

During the surveys off central California (T0142-06, T1075-02, T1102-04, T0215-01), southern California (T0664-10), and west of the Hawaiian Islands, (T0296-12), unidentified Hydrolagus specimens were repeatedly observed (Fig. 1, Table 1). These records are of a large, bluish, short-nosed chimaera that had never before been observed previously in the central or eastern North Pacific. Surveys T0664-10, T0215-01, and, T0296-12 from the San Juan Seamount, Monterey Submarine Canyon, and from off the Hawaiian islands, respectively, were initially identified as $H$. cf. trolli by one of us (D.A. Ebert), and D.A. Didier (Millersville University) and L.A.K. Barnett (University California, Davis).

\section{Results and discussion Observations}

Hydrolagus cf. trolli from dive T-0142 (Fig. 2a) was the first observation of these unknown bluish Hydrolagus specimens in the Northern Hemisphere, and the first of four observations from Monterey Bay, California. Specimen from trawl T-0142 was first reported by Lundsten et al. 2009, and recorded off the coast of central California at the Davidson Seamount on 9 May 2000 at approximately $2064 \mathrm{~m}$. A similar specimen was observed near the same location on dive $\mathrm{T}-1102$ (Fig. 2b) at the Davidson Seamount, on 20 June 2007, at approximately $1641 \mathrm{~m}$. Both specimens from dives T-0142 and T-1102 have striking similarities including: a short, pointed snout, with preopercular and oral canals that share a common branch from the infraorbital canal, bluish-grey body coloration, a concave first dorsal fin with keeled spine, large, triangular pectoral fins, and broad pelvic fins. Additionally, the dorsal, pectoral, and pelvic fins of these specimens all have a pale blue margin on the distal edge.

The third observation of this Hydrolagus species from Monterey Bay, CA was identified from dive T-0215 in the Monterey Canyon, on 5 October 2000, at approximately $1679 \mathrm{~m}$ (Fig. 2c). A fourth specimen was observed on dive T-1075 (Fig. 2d), also in the Monterey Canyon on 24 January 2007 at approximately $1658 \mathrm{~m}$. Specimens from dives T-1075 and T-0215 had similar morphological features to the Davidson Seamount specimens. The specimen observed on dive T-1075 had preopercular and oral canals sharing a common branch from the infraorbital canal on the left hand side, while these canals branched separately on the right side of the head. This could not be observed in the specimen from dive $\mathrm{T}-0215$ as the majority of the photos were from a dorsal view.

During a subsequent survey of seamounts off southern California, another large, bluish Hydrolagus specimen was observed. This specimen, also identified as $H$. cf. trolli, from dive T-0664 was recorded on 2 May 2004 on the San Juan Seamount at approximately $1629 \mathrm{~m}$ (Fig. 2e). The Hydrolagus specimen from this dive had a short pointed snout, large, triangular pectoral fins, and a bluish-grey coloration, consistent with those specimens observed on the Davidson Seamount.

A sixth observation of a $H$. cf. trolli specimen was during surveys off the western coast of the Hawaiian Islands. This was the first observation of $H$. cf. trolli from the central North Pacific. Hydrolagus cf. trolli from dive T-0296 was recorded on 16 April 2001 at approximately $1641 \mathrm{~m}$ (Fig. 2f). Although this Hydrolagus specimen was identified as $H$. cf. trolli it had several subtle differences from specimens T-0142 and T-0215 such as a short, blunt snout, and larger eyes. However, this specimen exhibited a few similar features to specimen T-0664. These similarities include: a keeled dorsal spine, longer than the height of the primary dorsal, and a short caudal filament.

Observations from all surveys show $H$. cf. trolli occurring over rocky substrates, sometimes over high relief outcrops. These observations suggest individuals typically occur over hard-bottom habitats or rocky, and mixed substrate patches with vertical relief. These observed substrate associations are in contrast to Hydrolagus melanophasma, which usually associates with soft bottom habitats (James et al. 2009). However, some eastern Pacific Hydrolagus species such as Hydrolagus mccoskeri, are known to associate with high relief habitats (James et al. 2009; Barnett et al. 2006). 


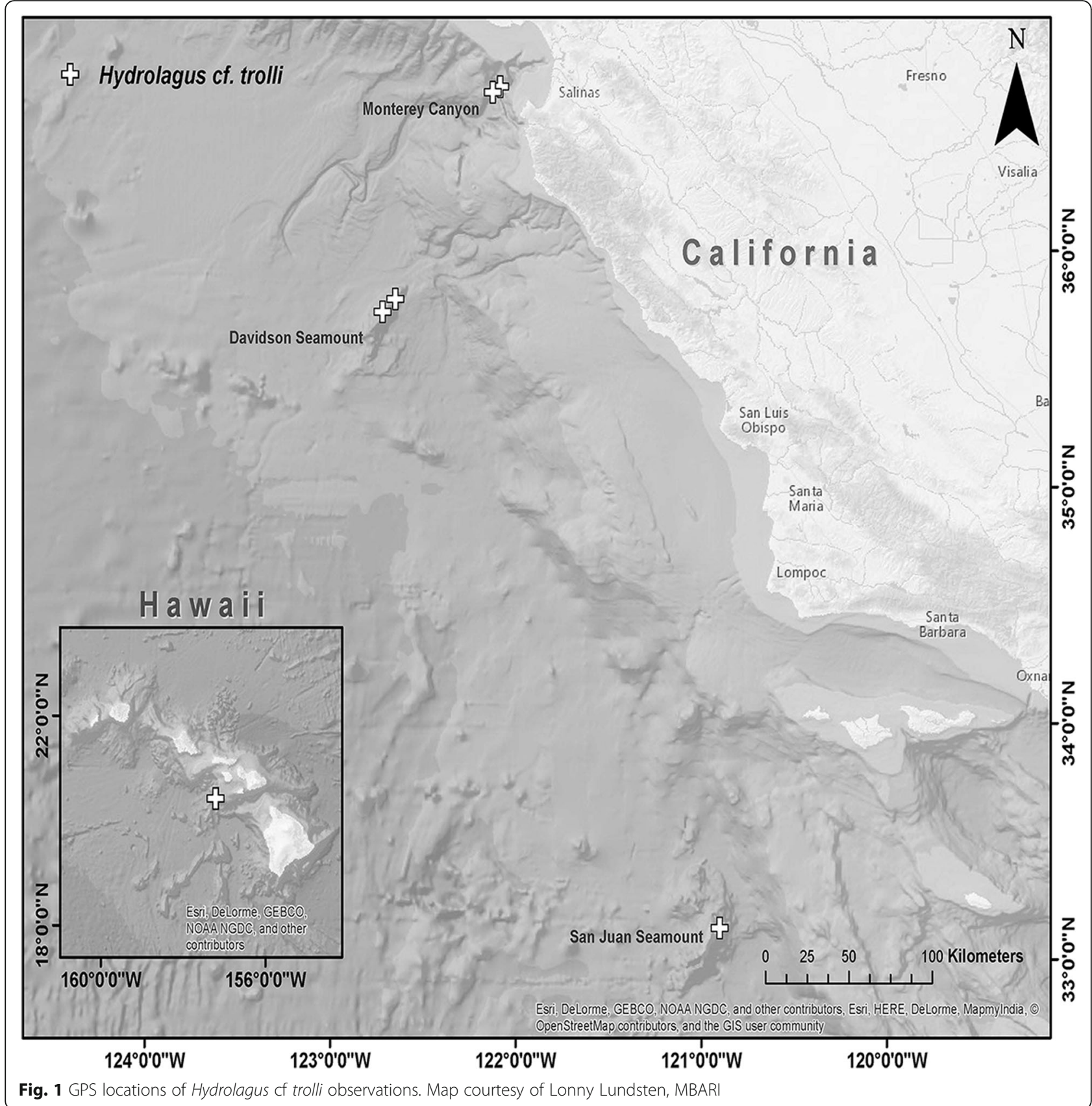

\section{Description}

Hydrolagus trolli is a highly distinctive chimaera species, often identified by a combination of the following characteristics: an even blue-gray to pale blue color, a pointed snout, a dark margin around the orbit with dark shadows along edges of the lateral line, and preopercular canal and oral canals usually sharing a common branch (Didier and Séret 2002; Compagno and Dagit 2006). Hydrolagus trolli is a large, although slender bodied species with a narrow head that evenly tapers to a whip-like tail. A caudal filament is present, although short and blunt. The pectoral fins of $H$. trolli are large and triangular, usually tapering to a point on the distal edge. The pelvic fins are broad, and square along distal edge. The first dorsal fin is triangular, with a concave distal edge (Didier and Séret 2002). The dorsal fin spine is curved anteriorly, with two small rows of serrations on the distal $1 / 3$ of the posterior surface. The fin spine is usually just shorter than the height of dorsal fin in juveniles, and slightly longer in adults. The second dorsal fin is elongate, sloping, relatively even in height, and is connected to the dorsal caudal fin by a narrow piece of skin. 
Table 1 CTD, GPS coordinates, and additional comments for observed Hydrolagus cf. trolli specimens

\begin{tabular}{|c|c|c|c|c|c|c|}
\hline Specimen & $\begin{array}{l}\text { Conductivity } \\
\text { (psu) }\end{array}$ & $\begin{array}{l}\text { Temperature } \\
\text { (C) }\end{array}$ & $\begin{array}{l}\text { Depth } \\
(\mathrm{m})\end{array}$ & Latitude/Longitude & Location & Comments \\
\hline T0142-06 & 34.49 & 2.01 & 2063.2 & $35.797391 /-122.650021$ & $\begin{array}{l}\text { Davidson } \\
\text { Seamount }\end{array}$ & $\begin{array}{l}\text { POP and O lateral line appear to share a common } \\
\text { branch. No claspers observed. }\end{array}$ \\
\hline T1102-04 & 34.37 & 2.45 & 1641.7 & $35.742034 /-122.71744$ & $\begin{array}{l}\text { Davidson } \\
\text { Seamount }\end{array}$ & $\begin{array}{l}\text { POP and O lateral line canal share a common branch. } \\
\text { No claspers observed. }\end{array}$ \\
\hline T0215-01 & 34.46 & 2.47 & 1679.6 & $36.671808 /-122.122993$ & $\begin{array}{l}\text { Monterey } \\
\text { Submarine } \\
\text { Canyon }\end{array}$ & $\begin{array}{l}\text { Coloration appears blue-purple. Short caudal filament. } \\
\text { No claspers observed. }\end{array}$ \\
\hline T1075-02 & 34.374 & 2.47 & 1658.3 & $36.695932 /-122.08455$ & $\begin{array}{l}\text { Monterey } \\
\text { Submarine } \\
\text { Canyon }\end{array}$ & $\begin{array}{l}\mathrm{POP} \text { and } \mathrm{O} \text { lateral line canal branch separately on } \\
\text { right side of head only. No claspers observed. }\end{array}$ \\
\hline T0664-10 & 34.49 & 2.58 & 1629.4 & $33.133464 /-120.90126$ & $\begin{array}{l}\text { San Juan } \\
\text { Seamount }\end{array}$ & $\begin{array}{l}\text { Coloration appears blue-purple. Short caudal filament. } \\
\text { No claspers observed. }\end{array}$ \\
\hline T0296-12 & 34.57 & 2.77 & 1640.8 & $20.426773 /-157.223329$ & Hawaii & $\begin{array}{l}\text { Snout more compressed, similar to H. purpurescens. } \\
\text { No claspers observed. }\end{array}$ \\
\hline
\end{tabular}

The caudal fin is rounded with dorsal and ventral lobes nearly equal in height, though ventral lobe is slightly longer (Didier and Séret 2002). Males have a deeply curved frontal tenaculum, which is distally upturned with spines along the dorsal edge; and pelvic claspers that have fleshy, pale, distal lobes, divided for $1 / 3$ their length, with tips usually extending beyond distal edge of pelvic fin (Didier and Séret 2002).

\section{Comparisons}

Hydrolagus cf. trolli is the third species of Hydrolagus observed in the eastern North Pacific, and is the second species observed from the central North Pacific. Hydrolagus cf. trolli is morphologically distinct from the other two eastern North Pacific Hydrolagus species, Hydrolagus colliei and Hydrolagus melanophasma, in coloration. The overall brownish-red color and white spots of $H$.
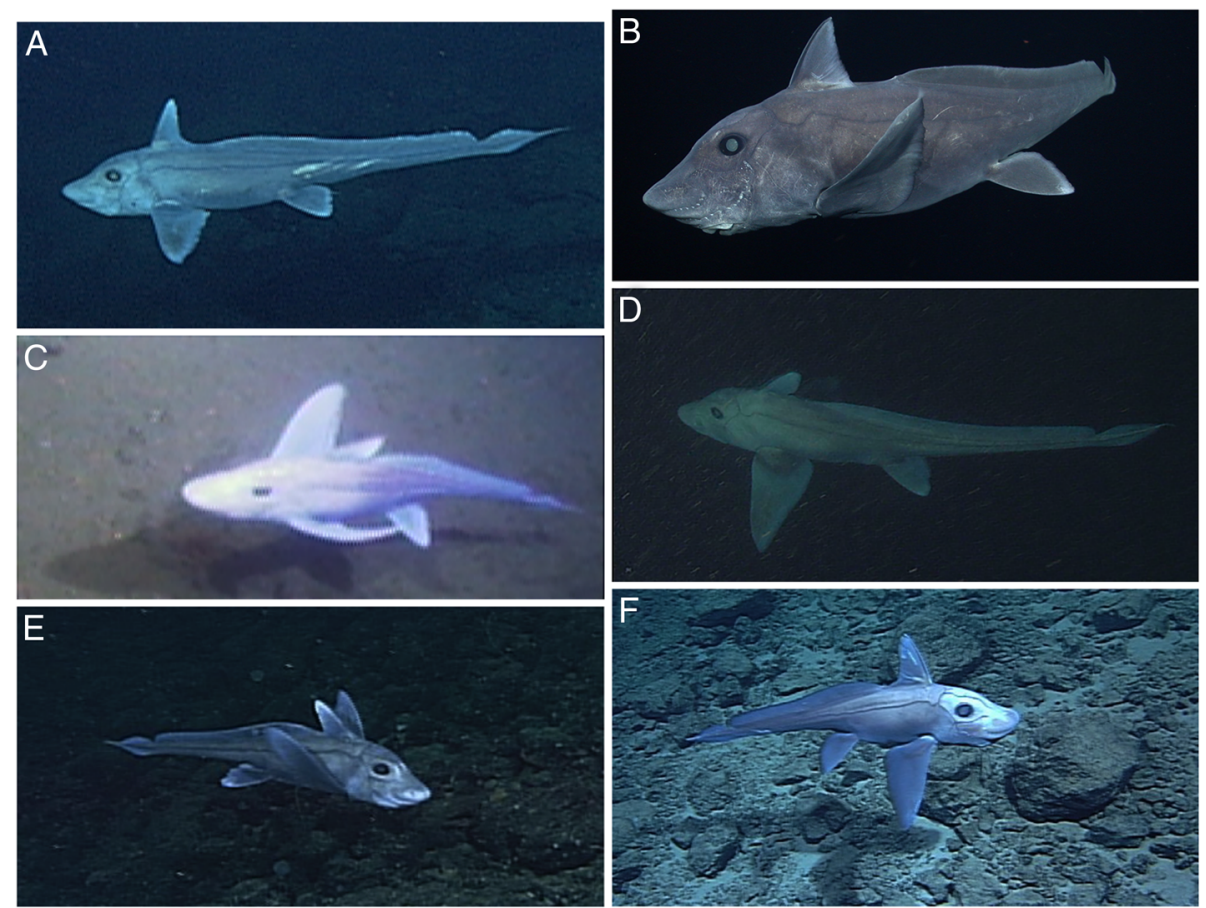

Fig. 2 a Hydrolagus of trolli specimen T-0142 full-length lateral view. b Hydrolagus cf trolli specimen T-1102 lateral view, close up. c Hydrolagus cf trolli specimen T-0215 dorsal view. d Hydrolagus of trolli li specimen T-1075 lateral view. e Hydrolagus of trolli specimen T-0664 full-length lateral view. f Hydrolagus of trolli specimen T-0296 lateral view, over rocky substrate 
colliei, and overall dark, black coloration of $H$. melanophasma are easily distinguished from the even blue color of $H$. cf. trolli (Ebert 2003).

The only Hydrolagus species currently known from the central North Pacific is Hydrolagus purpurescens (Gilbert 1905) that was described from Hawaiian waters. It closely resembles $H$. cf. trolli specimens, but differs from it in body coloration, pectoral fin shape, and dorsal spine length and shape. Hydrolagus purpurescens is thought to be more widespread throughout the central and western North Pacific, though similar bottom depth $\sim 1130 \mathrm{~m}$. Despite possible overlapping geographically with $H$. cf. trolli these two species are morphologically different in several aspects. The head of $H$. purpurescens is robust and deeply compressed, with a snout that is high and compressed, while the observed specimens had pointy snouts (Gilbert 1905; Garman 1911). The pectoral fins of $H$. purpurescens are large, and broad (Gilbert 1905; Garman 1911), while our specimens had pectoral fins more pointed, and triangular. Hydrolagus purpurescens has a straight dorsal spine that is longer than the height of the first dorsal fin, with no serrations (Gilbert 1905; Garman 1911). Dorsal fin spines of our H. cf. trolli specimens were keeled, except for the specimens observed on dives T-0142, and T-0215 where the fin spines could not be observed in detail. Finally, the even blackpurple to purplish-plum coloration of $H$. purpurescens is distinct from the grey and blue coloration of our $H$. cf. trolli specimens. All the observed $H$. cf. trolli specimens have characteristics that more closely resemble $H$. trolli than $H$. purpurescens.

\section{Remarks}

The presence of Hydrolagus cf. trolli increases the number of known Hydrolagus species to three off California, and to two species off the Hawaiian Islands. Our specimens cannot yet be confirmed as Hydrolagus trolli until morphometric data and or DNA samples from preserved specimen have been collected and analyzed. However, these observations by ROVs suggest that even in relatively well-known areas much remains to be elucidated on the Chondrichthyan fauna from these regions.

\section{Acknowledgements}

We are grateful for support from the pilots of the ROV Tiburon and the crew of the R/V Western Flyer. We thank D. Clague, S. Haddock, and P. Lonsdale for use of video observations. We thank D.A. Didier (Millerville University), L.A.K. Barnett (University California, Davis) for taxonomic assistance and L. Kuhnz (MBARI) for technical assistance. This work was partially supported by the David and Lucile Packard Foundation's funding of MBARI.

\section{Author details}

${ }^{1}$ Pacific Shark Research Center, Moss Landing Marine Laboratories, 8272 Moss Landing Road, Moss Landing, CA 95039, USA. ${ }^{2}$ Monterey Bay Aquarium Research Institute, 7700 Sandholdt Road, Moss Landing, CA 95039, USA.

${ }^{3}$ Department of Ichthyology Research Associate, California Academy of Sciences, 55 Music Concourse Drive, San Francisco, CA 94118, USA.

Received: 8 September 2016 Accepted: 8 September 2016 Published online: 11 October 2016

\section{References}

Aguirre-Villaseñor H, Salas-Singh C, Madrid-Vera J, Martínez-Ortiz J, Didier DA, Ebert DA. New Eastern Pacific records of Hydrolagus melanophasma with annotations of a juvenile female. J Fish Biol. 2013;82:714-24.

Andrade I, Pequeño G. First record of Hydrolagus pallidus Hardy \& Stehmann, 1990 (Chondrichthyes: Chimaeridae) in the Pacific Ocean, with comments on Chilean holocephalians. Revista de Biología Marina y Oceanografía, 2006; 41(1):111-115.

Angulo A, López MI, Bussing WA, Murase A. Records of chimaeroid fishes (Holocephali: Chimaeriformes) from the Pacific coast of Costa Rica, with the description of a new species of Chimaera (Chimaeridae) from the eastern Pacific Ocean. Zootaxa. 2014;3861(6):554-574.

Barnett LK, Didier DA, Long DJ, Ebert DA. Hydrolagus mccoskeri sp. nov., a new species of chimaeroid fish from the Galapagos Islands (Holocephali: Chimaeriformes: Chimaeridae). Zootaxa. 2006;1328:27-38.

Bustamante C, Flores H, Concha-Pérez, Y. First record of Hydrolagus melanophasma James, Ebert, Long \& Didier, 2009 (Chondrichthyes, Chimaeriformes, Holocephali) from the southeastern Pacific Ocean. 2012. 236-242

Compagno LJV, Dagit DD. Hydrolagus trolli. 2006. The IUCN Red List of Threatened Species, Version 2014.2. <http://www.iucnredlist.org/details/ 60197/0> Downloaded on 11 August 2014.

Didier DA, Kemper JM, Ebert DA. Phylogeny, biology, and classification of extant Holocephali. In: Carrier JC, Musick JA, and Heithaus M.R. (eds) Biology of Sharks and their Relatives 2nd edition. CRC Press, Boca Raton. 2012.

Didier DA, Séret B. Chimaeroid Fishes of New Caledonia with Description of a New Species of Hydrolagus (Chondrichthyes, Holocephali). Cybium. 2002; 26(3):225-33.

Ebert DA. Sharks, Rays, and Chimaeras of California. Berkeley: University of California Press; 2003. p. 284.

Ebert DA, van Hees KE. Beyond jaws: rediscovering the "Lost Sharks" of southern Africa. In: Ebert, D.A., Huveneers, C., \& Dudley, S.F.J. (eds). Advances in shark research. African Journal of Marine Science. 2015.37(2):141-156.

Garman S. The Chismopnea (chimaeroids). Mem Mus Comp Zool. 1911;40:79-101.

Gilbert, C.H. Deep sea fishes of the Hawaiian Islands. In: D.S. Jordan \& B.W. Evermann. The Aquatic Resources of the Hawaiian Islands. Bulletin of the U.S. Fish Commission for 1903. 1905. 23:575-713.

James KC, Ebert DA, Long DJ, Didier DA. A new species of chimaera, Hydrolagus melanophasma sp. Nov. (Chondrichthyes: Chimaeriformes: Chimaeridae), from the eastern North Pacific. Zootaxa. 2009;2218:59-68.

Kemper JM, Ebert DA, Naylor G, Didier DA. Chimaera carophila (Chondrichthyes: Chimaeriformes: Chimaeridae), a new species of chimaera from New Zealand. Bull Mar Sci. 2015;91(1):63-81.

Last PR, Stevens JD. Sharks and rays of Australia. Melbourne: CSIRO Publishing; 2009. p. 656.

Lundsten L, McClain CR, Barry JP, Cailliet GM, Clague DA, DeVogelaere AP. Ichthyofauna on Three Seamounts off Southern and Central California, USA Mar Ecol Prog Ser. 2009;389:223-32.

Schlining B, Jacobsen Stout N. MBARI's video annotation and reference system. Proceedings of the Marine Technology Society/Institute of Electrical and Electronics Engineers Oceans Conference, Boston. 2006, MA. pp. 1-5. 